\title{
Interaksi Pengetahuan dan Perceived Severity Kanker Serviks dengan Perilaku Pemilihan Pembalut Mahasiswi
}

\author{
Ambar Sulianti, Shofa Mutiara Arafah \\ Fakultas Psikologi UIN Sunan Gunung Djati Bandung, Indonesia \\ e-mail: ambarsulianti@uinsgd.ac.id
}

\begin{abstract}
Indonesia is the country with the highest number of cervical cancer sufferers in the world. Although the use of sanitary pads containing harmful whitening agents has been known as one of the predispositions of cervical cancer, the rate of cervical cancer continues to increase. This study aims to analyze the relationship between knowledge and perceived severity of cervical cancer with the behavior of choosing sanitary napkin in college students. This study used a quantitative method of cross-sectional study on 125 research subjects. The results showed that there were no significant differences in the selection of pads both in the knowledge of high and low cervical cancer. However, there is interaction between high knowledge and high perceived severity on sanitary pads selection.
\end{abstract}

Keywords: cervical cancer, college students, bandages, knowledge, perceived severity

\begin{abstract}
Abstrak
Indonesia merupakan negara dengan jumlah penderita kanker serviks terbanyak di dunia. Meskipun penggunaan pembalut yang mengandung zat pemutih berbahaya telah diketahui sebagai salah satu predisposisi terjadinya kanker serviks, angka kanker serviks terus mengalami peningkatan. Penelitian ini bertujuan untuk menganalisis hubungan pengetahuan dan perceived severity kanker serviks dengan perilaku pemilihan pembalut mahasiswi. Penelitian ini menggunakan metode kuantitatif studi cross-sectional pada 125 subjek penelitian. Hasil penelitian menunjukkan bahwa tidak terdapat perbedaan signifikan pemilihan pembalut baik pada pengetahuan kanker serviks tinggi maupun rendah. Namun terdapat interaksi antara pengetahuan tinggi dan perceived severity yang tinggi dalam pemilihan pembalut.
\end{abstract}

Kata Kunci: kanker serviks, mahasiswa, pembalut, pengetahuan, perceived severity

\section{Pendahuluan}

Penyakit kanker serviks merupakan penyakit kanker dengan prevalensi tertinggi di Indonesia pada tahun 2013, yaitu kanker serviks sebesar $.8 \%$ (Kementerian Kesehatan RI, 2015). Jumlah penderita kanker serviks terus meningkat. Pada tahun 2015 penderita kanker serviks di Indonesia menempati urutan teratas di negara berkembang dan berada pada urutan ke-10 di negara maju atau urutan ke-5 secara global. Menurut World Health Organization (WHO), Indonesia merupakan negara dengan jumlah penderita kanker serviks terbesar di dunia (Kementerian
Kesehatan RI Pusat Data dan Informasi Kesehatan, 2015). Angka mortalitas (kematian) akibat kanker serviks sangat tinggi. Di Indonesia, dilaporkan setiap 1 jam ada 1 wanita yang meninggal karena kanker ganas ini. Diperkirakan kematian akibat kanker serviks ini akan terus meningkat sebesar $25 \%$ dalam kurun waktu 10 tahun mendatang jika tidak dilakukan tindakan pencegahan dan penatalaksanaan yang tepat (Kementerian Kesehatan RI Pusat Data dan Informasi Kesehatan, 2015).

Kanker serviks disebabkan oleh virus Human Papilloma Virus (HPV) dengan predisposisi antara lain perilaku sering 
berganti-ganti pasangan seks dan perilaku yang tidak higienis pada saat menstruasi. Di Indonesia, ditemukan bahwa predisposisi utama kanker mulut rahim adalah pembalut berkualitas buruk. Pembalut merupakan kebutuhan yang urgen bagi perempuan sewaku menstruasi. Pada pembalut yang banyak beredar, bahan penyerap (absorbent agent) pada pembalut diputihkan dengan menambahkan berbagai zat kimia dan pemutih klorin sehingga menghasilkan pembalut dengan tampilan putih. Riset EPA (Environmental Protection Agency) menunjukkan bahwa rerata zat-zat berbahaya tersebut di dalam setiap pembalut mengandung sekitar 400 ppt (Julina, 2012). Penelitian oleh Yayasan Kanker Indonesia menunjukkan dari 9 sampel pembalut merek terkenal di Indonesia, seluruhnya mengandung klorin dengan besar kandungan klorin secara berurutan $6.05 \mathrm{ppm} ; 7.3 \mathrm{ppm} ; 7.77 \mathrm{ppm}$; 7.93 ppm; 8.23 ppm; 17.74 ppm; 24.44 ppm; $39.2 \mathrm{ppm}$ dan tertinggi $54.73 \mathrm{ppm}$ (Tempo, 2015). Kementerian Kesehatan RI menetapkan batas maksimal klorin yang aman untuk digunakan adalah 5 ppm (Devianti \& Yulianti, 2018).

Masalah kesehatan reproduksi mendapat perhatian dari seluruh negara di dunia, bukan hanya masalah dalam skala nasional, tetapi juga dalam skala internasional. Di Amerika, undang-undang keamanan pembalut berdioksin, diperkenalkan pada Kongres di New York pada Januari 2003. National Institutes of Health (NIH) meneliti risiko kesehatan pada wanita akibat penggunaan dioksin termasuk endometriosis dan kanker serviks (Association, 2009). Dioksin mengganggu proses di dalam gen sel. Dioksin memasuki sel, berikatan dengan protein reseptor Aril hidrokarbon (AhR) yang terdapat pada berbagai organ tubuh termasuk hati, paruparu, limfosit, dan plasenta. Begitu terikat pada AhR, dioksin dapat bergerak bebas di dalam sel, dan mengikat DNA di dalam nukleus. Gen yang ditargetkan oleh dioxin memengaruhi metabolisme hormon dan faktor pertumbuhan, dan dengan demikian memengaruhi fungsi reproduksi, endokrin, dan kekebalan tubuh. Karena hal tersebut para ahli kesehatan di negara maju merekomendasikan untuk menggunakan katun organik dan tidak menambahkan pemutih (Schecter, Birnbaum, Ryan, \& Constable, 2006).

Penyakit kanker serviks disebabkan oleh Human Papilloma Virus (HPV). Dalam kondisi tertentu seperti kurang penjagaan kebersihan daerah kewanitaan saat mensturasi dapat memicu perkembangan HPV. Sebuah studi menyebutkan bahwa $83 \%$ perempuan Indonesia berisiko terjangkit infeksi vagina dan $62 \%$ dari statistik tersebut berhubungan dengan pemakaian pembalut. Penelitian lain menunjukkan bahwa perilaku remaja dalam perawatan sistem reproduksi selama menstruasi masih kurang bagus (Tantry, Solehati, \& Yani, 2019).

Kanker serviks termasuk penyakit yang dapat dicegah karena mempunyai fase prakanker yang cukup panjang. Kejadian kanker serviks membutuhkan proses dari 3 sampai 20 tahun yang dimulai dari infeksi HPV sampai menjadi kanker. Oleh karena itu remaja harus sudah memulai usaha untuk mencegah kanker serviks. Fase prakanker belum menimbulkan gejala atau keluhan berarti. Salah satu cara mencegah kanker serviks diantaranya dengan menerapkan perilaku sehat pada kehidupan sehari-hari, yaitu dengan cara menjaga kebersihan alat kelamin, menjaga kebersihan pakaian dalam, tidak bertukar handuk, menghindari celana ketat, menghindari cuci vagina dengan sabun, mencuci tangan sebelum mencuci alat kelamin, sering mengganti pembalut, memilih pembalut yang baik, dan mengelola stres (Abrori, Hernawan, \& Ermulyadi, 2017; Kusumawati, Wiyasa, \& Rahmawati, 2016; Nurachmah \& Mutikasari, 2009; Setyowati, 2012; Wahyuni, 2013).

Telah banyak penelitian menemukan bahwa insiden kanker serviks pada usia muda semakin meningkat dan jenis kanker 
semakin agresif (Rasjidi, 2009). Untuk itu pencegahan penyakit ini sejak perempuan usia remaja menjadi penting. Memasuki usia remaja, setiap perempuan akan mengalami suatu masa yang disebut menstruasi. Proses ini merupakan hal alamiah karena terjadinya pelepasan dinding rahim (endometrium) yang disertai dengan pendarahan. Dengan demikian salah satu hal yang menjadi perhatian penting adalah pemilihan pembalut pada remaja putri. Pembalut perempuan adalah alat pembantu vital pada perempuan yang sedang mengalami menstruasi.

Pembalut merupakan kebutuhan yang harus ada ketika menstruasi. Pemilihan pembalut didasarkan kepada manfaat dan efek yang ditimbulkan dari pemakaian pembalut tersebut. Perempuan yang memerhatikan kesehatannya akan memilih pembalut yang baik. Jika dilihat dari pemaparan di atas, perilaku perempuan dalam menggunakan berbagai merek pembalut dipengaruhi oleh adanya perceived severity. Perceived severity adalah kepercayaan subjektif individu dalam menyebarnya penyakit disebabkan oleh perilaku atau percaya seberapa berbahayanya penyakit sehingga menghindari perilaku tidak sehat agar tidak sakit. Keyakinan akan terkena penyakit merupakan salah satu dari tiga unsur psikologis utama yang terkait dengan perilaku pencegahan penyakit (Sur, 2015).

Taylor mengemukakan bahwa derajat/ tingkat dimana seseorang percaya bahwa dirinya memiliki ancaman kesehatan dalam dirinya (perceives a personal health threat) dan persepsi terhadap penerapan perilaku kesehatan secara khusus sangat efektif dalam mengurangi ancaman kesehatan. Persepsi akan ancaman penyakit dipengaruhi oleh penilaian secara umum mengenai kesehatannya (general health values) termasuk ketertarikan dan perhatian tentang kesehatan, keyakinan spesifik tentang kerentanan (vulnerability) terhadap penyakit khusus, serta keyakinan terhadap konsekuensi dari penyakit, seperti tingkat keparahan dari konsekuensi terkena suatu penyakit (Glanz, Rimer, \& Viswanath, 2008).

Berdasarkan studi pendahuluan kepada 30 mahasiswi Sekolah Tinggi Ilmu Kesehatan (STIKes), 28 diantaranya masih menggunakan pembalut berklorin meskipun mereka mengetahui bahaya pembalut tersebut. Sikap memilih pembalut adalah pola tingkah laku seseorang atau kelompok dalam memilih untuk memenuhi kebutuhan biologisnya yang meliputi sikap, kepercayaan dan pemilihan pembalut. Sikap orang terhadap pembalut dapat bersifat positif dan negatif, yang mana sikap positif atau negatif ini bersumber dari nilai-nilai afektif yang berasal dari lingkungan (alam, budaya, sosial dan ekonomi) dimana seseorang atau kelompok itu tumbuh. Demikian juga halnya dengan kepercayaan terhadap pembalut yang berkaitan dengan nilai-nilai kognitif, yaitu kualitas baik atau buruk, dan menarik atau tidak menarik. Pemilihan adalah proses psikomotor untuk memilih dan mengonsumsi pembalut sesuai dengan sikap dan kepercayaan yang diyakini.

Pemilihan pembalut berkaitan dengan preferensi pribadi yaitu pilihan suka atau tidak suka oleh seseorang terhadap produk (barang dan jasa) yang digunakan. Personal preference seseorang dapat dilihat dari suka atau tidak suka dalam pemilihan atau penolakan pembalut. Personal preference pemilihan pembalut didasarkan pada penerimaan budaya, status ekonomi, dan ketersediaan di pasar lokal (Kaur, Kaur, \& Kaur, 2018). Dalam memilih dan membeli pembalut, pengalaman seseorang sangat memengaruhi dan menjadi landasan yang kuat. Tampilan pembalut pun merupakan hal yang cukup banyak memengaruhi preferensi dan minat seseorang. Dengan demikian seorang perempuan mempertimbangkan antara tampilan dan nilai kesehatan dalam memilih dan membeli pembalut.

Studi pendahuluan pada sejumlah mahasiswi STIKes yang notabene telah 
mengetahui fakta klorin pada pembalut, tidak menjamin pemilihan pembalut bebas klorin. Dengan demikian perlu diteliti interaksi keterlibatan faktor lain dalam pemilihan pembalut. Namun, hingga saat ini belum ada yang melakukan penelitan mengenai hal tersebut. Penelitian ini bertujuan untuk menganalisis interaksi pengetahuan dan perceived severity kanker serviks terhadap pemilihan pembalut.

\section{Penyebab Kanker Serviks}

Infeksi oleh human papilloma virus (HPV) adalah faktor risiko paling penting untuk terjadinya kanker serviks. HPV merupakan kelompok virus dengan jenis lebih dari 150 virus. Beberapa dari HPV menyebabkan sejenis pertumbuhan yang disebut papilloma, yang lebih dikenal sebagai kutil. HPV dapat menginfeksi sel di permukaan kulit, dan mereka yang melapisi genital, anus, mulut dan tenggorokan, tetapi bukan darah atau organ internal seperti jantung atau paru-paru (Society, 2016).

HPV dapat menular dari satu orang ke orang lain selama kontak kulit-ke-kulit. Penyebaran HPV melalui aktivitas seksual, termasuk seks vagina, anal, dan bahkan oral. HPV sangat terkait kanker, termasuk kanker serviks, vulva, dan vagina pada wanita, kanker penis pada pria, dan kanker anus, mulut, dan tenggorokan baik pada pria maupun wanita.

\section{Tugas Perkembangan Usia Mahasiswi}

Mahasiswi berada dalam usia perkembangan remaja akhir. Remaja akhir berusia antara 17-19 tahun merupakan masa konsolidasi menuju periode dewasa. Terdapat beberapa tugas perkembangan psikologis yang perlu dicapai yaitu (Badaryati, 2012; Na'mah, 2014): 1) Minat yang semakin mantap terhadap fungsifungsi intelek. 2) Ikatan terhadap pekerjaan/ tugas, remaja mulai mencintai suatu bidang tertentu yang ditekuni secara mendalam. 3) Egonya mencari kesempatan untuk bersatu dengan orang-orang lain dan dalam pengalaman-pengalaman baru. Ke- inginan untuk menjauhkan diri dari orang tua semakin jelas, remaja mulai merasakan kebebasan tetapi juga merasa kurang menyenangkan. 4) Terbentuk identitas seksual yang lebih mantap, diikuti pengembangan nilai moral dan etisnya. 5) Egosentrisme (terlalu memusatkan perhatian pada diri sendiri) diganti dengan keseimbangan antara kepentingan diri dengan orang lain. 6) Pengembangan hubungan pribadi yang labil. Terbentuknya kestabilan diri remaja diperlukan tokoh panutan atau hubungan cinta yang stabil. 7) Penghargaan kembali pada orang tua dalam kedudukan yang sejajar. Pada masa remaja akhir, remaja putri biasanya membentuk kelompok-kelompok kecil yang saling berbagi perasaan dan pengalaman (Badaryati, 2012).

\section{Peran Pengetahuan bagi Pembentukan Perilaku Remaja dalam Penjagaan Sistem Reproduksi}

Teori pembelajaran Behavioristik berisi tentang penjelasan mengenai pembelajaran yang difokuskan pada kejadiankejadian eksternal sebagai penyebab perubahan pada perilaku yang dapat diobservasi. Beberapa prinsip dalam teori belajar behavioristik, meliputi: (1) Reinforcement and punishment; (2) Primary and secondary reinforcement;

Schedules of reinforcement; (4) Contingency management; (5) Stimulus control in operant learning; (6) The elimination of responses. Menurut Watson (Pungkasuri, 2014), pendidikan sangat berpengaruh terhadap perkembangan dan menentukan kemampuan seseorang. Hal ini didasari pada teori bahwa manusia dilahirkan dengan kemampuan yang sama antara satu individu dengan individu lainnya.

Pengetahuan kanker serviks bukanlah sesuatu yang sudah ada serta tersedia dan sementara orang tinggal menerimanya, namun sebagai suatu pembentukan yang terus-menerus oleh seseorang yang setiap saat mengalami reorganisasi karena adanya pemahaman-pemahaman baru yang muncul 
(Purwatiningsih, 2006). Pengetahuan dan kognisi tentang reproduksi merupakan domain yang sangat penting untuk terbentuknya tindakan seseorang dalam mencegah kanker serviks (Efrida, 2013). Upaya peningkatan pencegahan kanker serviks dapat dilakukan dengan penyuluhan pengetahuan reproduksi (Septadina, Kesuma, Handayani, Suciati, \& Liana, 2015; Setyowati, 2012). Wulandari menyebutkan dari studi literaturnya bahwa banyak kejadian kanker serviks ada kaitannya dengan masih rendahnya tingkat pengetahuan tentang faktor risiko dan pencegahan kanker serviks (Wulandari, 2016).

\section{Pembentukan Perilaku Kesehatan Ditinjau dari Neurosains}

Dalam perkembangan awal neurosains, masalah pikiran/ otak merupakan unsur utama karena ahli Fisiologi dan Psikologi berfokus pada sifat dan lokalisasi pikiran serebral. Sebagai contoh, seseorang dapat menemukan ide-ide tentang jiwa global terlokalisasi ke otak dalam karya Phytagoras, Hippocrates, Plato, Erisistratus, dan Galen. Ahli Fisiologi pneumatik menempatkan kapasitas mental pada cairan ventrikel serebri, seperti yang tertuang dalam buku De Functionibus Systematis Nervosa diterbitkan oleh Jiri Prochaska dan peralihan penelitian ke batang otak dan otak besar (Tan, 2007). Dengan berkembangnya penelitian, Franz Josef Gall mengemukakan bahwa ada korelasi antara karakter dan tanda-tanda kronologis eksternal: ukuran dan bentuk kepala mencerminkan ukuran dan bentuk bagianbagian yang mendasari otak, kemampuan mental bawaan dan tetap, dan pengembangan kemampuan bawaan adalah refleksi dari ukuran yang diwariskan dari otaknya. Dengan demikian, kemampuan yang berkembang dengan baik dapat diprediksi dari daerah yang sangat menonjol dari tempurung kepala (lokalisasi fungsional dari kemampuan dalam tempurung kepala). Meskipun pendekatan korelasional Gall akhirnya ditinggalkan, pencapaiannya dalam sejarah lokalisasi fungsional tidak dapat diremehkan; ia adalah pendiri psikologi fungsional yang berbasis biologis. Perkembangan neurosains dalam 200 tahun kemudian, menemukan bahwa kemampuan kognitif dapat diprediksi dari pengukuran kraniofasial (Tan, 2007).

Sejalan dengan berkembangnya teknologi, terdapat pemikiran yang menyangkal pendapat lama. Locke dan Hume mengklaim bahwa semua mentalitas berdasarkan persepsi. Adapun pembentukan konsep adalah salinan dari persepsi, dan pemikiran adalah kombinasi dari konsep. Dari sudut pandang empiris, akan terlihat bahwa posisi yang lebih koheren mengenai fenomenologi kognitif akan menjadi pembatas, berdasarkan teori yang dimiliki para empirisi pemikiran (Grau, 2013). Dengan demikian respon perilaku merupakan respon yang kompleks, demikian pula hal-hal yang memengaruhi respon dalam memilih pembalut.

\section{Metode Penelitian}

Penelitian ini menggunakan metode kuantitatif komparasional terhadap mahasiswi berusia 18-21 tahun. Penelitian ini membandingkan pengetahuan dan perceived severity kanker serviks dalam hubungannya dengan pemilihan pembalut pada mahasiswi yang sedang menempuh pendidikan di STIKes yang memiliki kurikulum kesehatan reproduksi serta mahasiswi Fakultas Ushuludin dan Fakultas Syariah yang tidak dibekali pengetahuan kanker serviks di tempat kuliahnya. Total responden pada penelitian ini berjumlah 125 orang, 60 orang mahasiswi STIKes dan 65 orang mahasiswi non STIKes.

Instrumen yang digunakan pada penelitian ini berupa kuesioner. Kuesioner perceived severity dikembangkan dari dimensi-dimensinya yaitu: 1) Kepercayaan subjektif individu dalam menyebarnya penyakit disebabkan oleh perilaku; 2) Percaya bahayanya penyakit sehingga menghindari perilaku tidak sehat; 3) 
Persepsi keparahan yang akan diterima individu; serta 4) Dampak yang dirasakan saat sakit.

Jumlah soal kuesioner perceived severity yang telah melalui uji validitas dan normalitas sejumlah 23 item. Untuk kuesioner perceived barriers berjumlah 39 pernyataan yang dikembangkan dari dimensi-dimensinya yaitu: 1) Kepercayaan mengenai harga dari perilaku yang dilakukan; 2) Persepsi menurunnya kenyamanan saat meninggalkan perilaku tidak sehat; 3) Hubungan perceived barriers dengan perilaku sehat adalah negatif; serta 4) Persepsi hambatan terhadap perilaku sehat tinggi maka perilaku sehat tidak akan dilakukan.

Penilaian pemilihan pembalut dihitung berdasarkan skor:

1 : Memilih yang murah dan tersedia di tempat terdekat

2 : Memilih berdasarkan tampilan dan iklan yang menarik

3 : Memilih berdasarkan besarnya ukuran dan kenyamanan

4 : Memilih berdasarkan kandungan zat lebih dalam pembalut

5 : Memilih pembalut yang bebas pemutih klorin

Untuk mengetahui apakah skala mampu menghasilkan data yang akurat sesuai dengan tujuan ukurnya, diperlukan suatu proses pengujian validitas konstruk yaitu dilakukan dengan cara mengkorelasikan skor total tiap aspek atau dimensi atau komponen dengan skor total keseluruhan. Item diterima atau dianggap valid bila besarnya nilai koefisien korelasi antara skor total dimensi dengan skor total seluruh dimensi sebesar .50, sedangkan bila kurang dari .50 dianggap tidak memuaskan. Validitas alat ukur yang digunakan peneliti adalah korelasi Rank Spearman.

Uji hipotesis pada penelitian ini menggunakan uji non parametrik karena data tidak berdistribusi normal. Penelitian ini dilakukan dengan mengambil data mahasiswi yang berkuliah di Bandung dan sekitarnya. Waktu penelitian selama 4 bulan.

\section{Hasil Penelitian dan Pembahasan}

Deskripsi data hasil penelitian disajikan pada gambar 1. Gambar 1 memerlihatkan bahwa komposisi terbanyak responden sebanyak 53 orang memiliki rerata perceived severity 53.23 dengan skor memilih pembalut 1 (berdasarkan harga yang murah dan mudah diperoleh). Komposisi terbesar kedua yaitu 34 responden memilih pembalut berdasarkan besarnya ukuran pembalut dan kenyamanan. Kelompok yang memilih pembalut dengan kriteria bebas pemutih klorin (skor 5) menempati urutan paling sedikit sebanyak 5 orang dengan nilai perceived severity yang tinggi (rata-rata 93.80). Responden yang memilih pembalut berdasarkan tampilan dan iklan yang menarik, memiliki perceived severity yang cukup tinggi. Data perceived severity kemudian diuji normalitasnya dengan hasil diperlihatkan pada tabel 1 .

Tabel 1

Uji Normalitas Perceived Severity pada Kelompok Berpengetahuan Kanker Serviks

\section{Tests of Normality}

\begin{tabular}{lllllll}
\hline & \multicolumn{3}{c}{$\begin{array}{c}\text { Kolmogorov- } \\
\text { Smirnov }^{\mathrm{a}}\end{array}$} & \multicolumn{3}{c}{ Shapiro-Wilk } \\
\cline { 2 - 7 } & Statistic & df & Sig. & Statistic & df & Sig. \\
\hline $\begin{array}{l}\text { Perceived } \\
\text { Severity }\end{array}$ & .144 & 60 & .004 & .943 & 60 & .007
\end{tabular}

a. Lilliefors Significance

Correction

Berdasarkan tabel 1, data perceived severity pada kelompok berpengetahuan kanker serviks berdistribusi tidak normal. Oleh sebab itu analisis statistik yang dipilih adalah analisis non parametrik. Adapun deskripsi data hasil penelitian kelompok tidak berpengetahuan kanker serviks disajikan pada gambar 2 . 


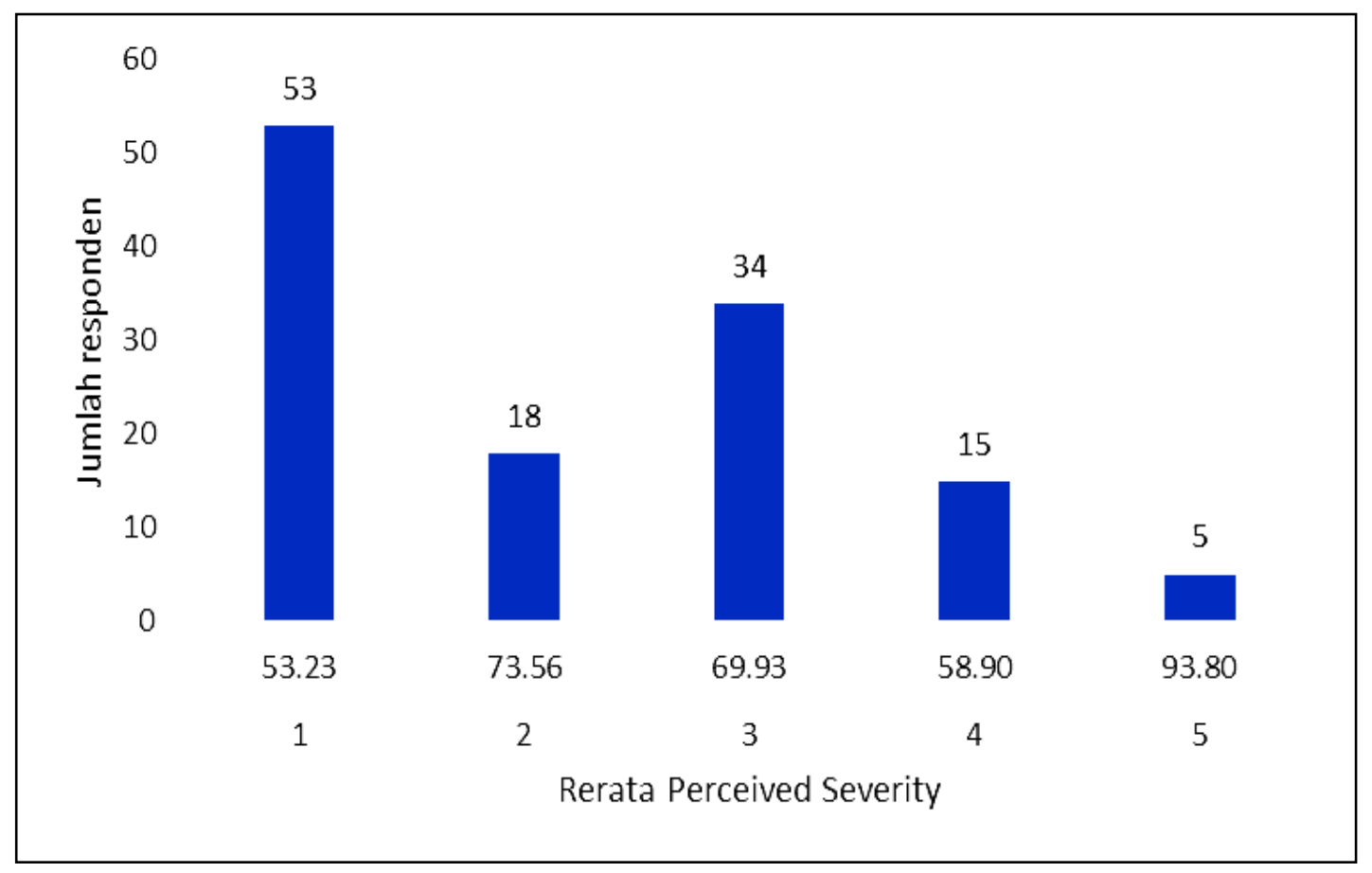

Gambar 1. Karakteristik kelompok dengan pengetahuan tinggi kanker serviks

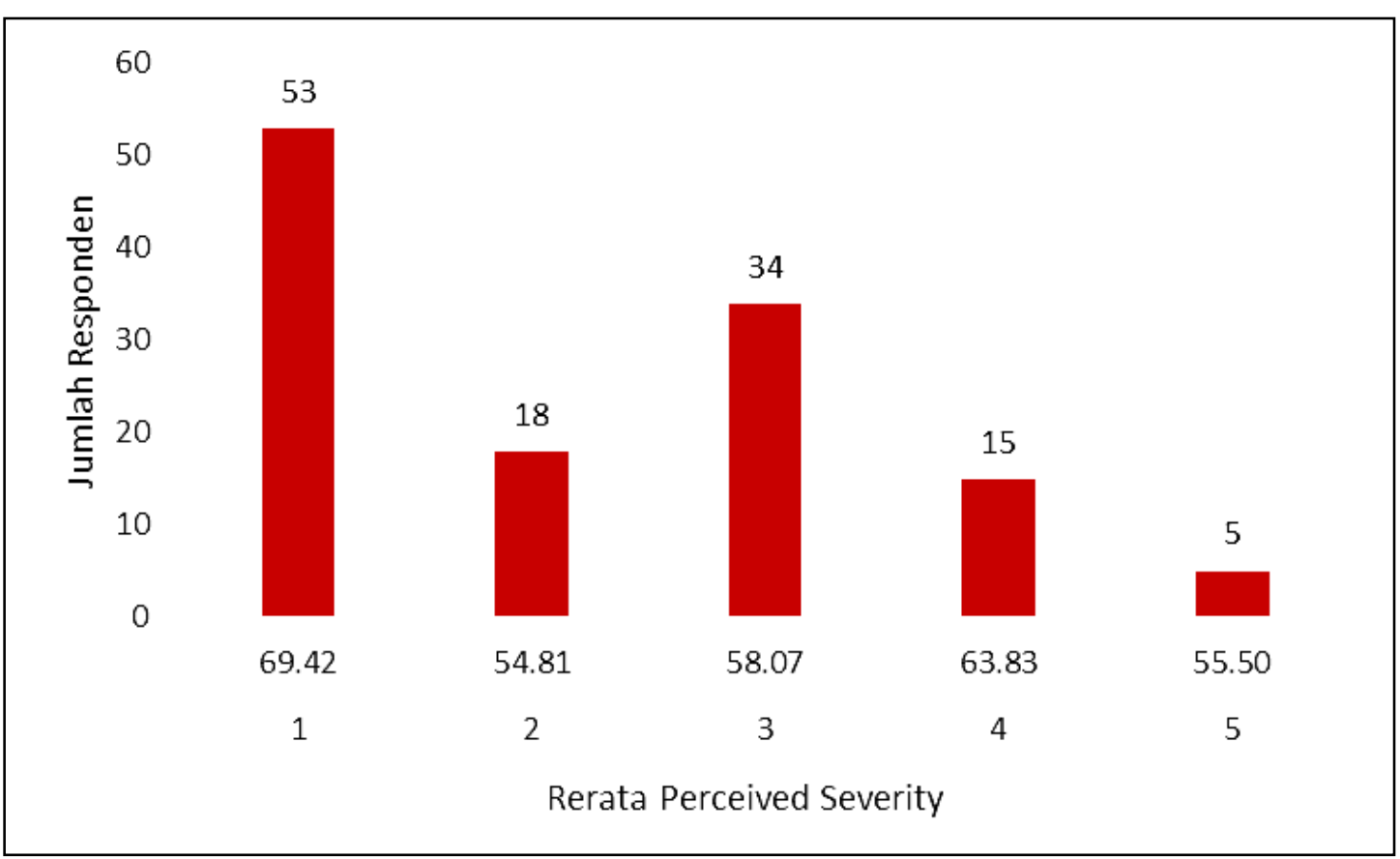

Gambar 2. Karakteristik kelompok dengan pengetahuan rendah kanker serviks

Gambar 2 menunjukkan sejumlah Responden yang memiliki perceived tinggi besar responden (53 orang) memilih dengan rerata 69.42 memiliki skor pembalut berdasarkan harga murah dan pemilihan pembalut terendah pada mudah memperolehnya (skor 1). kelompok tanpa pengetahuan kanker 
serviks yaitu memilih berdasarkan harga murah dan ketersediaan.

Terdapat persamaan antara kelompok yang memiliki pengetahuan tinggi kanker serviks dan pengetahuan rendah yaitu sama-sama didominasi oleh skor pemilihan pembalut yang rendah (memilih berdasarkan harga yang murah dan ketersediaan).

Menurut tim kerja Pendidikan Kesehatan dari WHO mengemukakan terdapat 4 alasan pokok (determinan) dalam perilaku. Pertama adalah thoughts and feeling (pemikiran dan perasaan), merupakan modal awal seseorang untuk bertindak/ berperilaku. Kedua, personal inference (acuan) yaitu referensi dari seseorang atau pribadi yang dipercayai. Ketiga, resources (sumber daya) merupakan pendukung dalam membentuk perilaku seseorang seperti sarana prasarana atau fasilitas. Terakhir, culture (sosial budaya) merupakan faktor eksternal yang memengaruhi terbentuknya perilaku.

Dengan demikian berdasarkan teori perilaku kesehatan dari WHO, yang pertama memengaruhi perilaku kesehatan adalah thoughts and feeling, dalam hal ini thoughts secara terpisah tidak berpengaruh terhadap pemilihan pembalut. Gambar 1 dan gambar 2 menunjukkan bahwa baik kelompok yang memiliki pengetahuan tinggi tentang kanker serviks maupun pengetahuan rendah tentang kanker serviks sama-sama dominan memilih pembalut dengan skor 1 yaitu memilih berdasarkan harga yang murah dan keterjangkauan. Pemilihan berdasarkan pembalut terbanyak justru berdasarkan resources yaitu ketersediaan keuangan dan kemudahan memperolehnya. Pada kelompok yang memiliki pengetahuan tinggi, mereka tahu bahwa pembalut merupakan salah satu predisposisi untuk terjadinya kanker serviks, namun dorongan berdasarkan resources mengalahkan thought and feeling perilaku seseorang (Badaryati, 2012). Hal ini sesuai dengan teori yang dikemukakan Lordo bahwa banyak aspek selain pengetahuan yang membentuk health belief model (Lordo, 2018).

Analisis statistik dilakukan untuk melihat perbedaan pemilihan pembalut dan perceived severity pada kelompok dengan pengetahuan kanker serviks tinggi dan rendah. Hasil pengujian Kruskal Wallis disajikan pada tabel 2 .

Tabel 2

Hasil Analisis Statistik Non Parametrik

Test Statistics $^{\text {a,b }}$

\begin{tabular}{lcc}
\hline & $\begin{array}{c}\text { Perceived } \\
\text { Severity }\end{array}$ & $\begin{array}{c}\text { Pengetahuan } \\
\text { Reproduksi Kanker }\end{array}$ \\
\hline Chi-Square & 10.522 & 4.585 \\
Df & 4 & 4 \\
Asymp. Sig. & .032 & .333 \\
\hline
\end{tabular}

a. Kruskal Wallis Test

b. Grouping Variable: Skor Pemilihan Pembalut

Tabel 2 menunjukkan bahwa pengetahuan kanker serviks secara terpisah, dari uji statistik tidak memengaruhi pemilihan pembalut. Remaja akhir, sesuai dengan tugas perkembangan pada remaja yang dikemukakan oleh Havighurst disebutkan bahwa individu yang memasuki tahap tersebut, diharapkan mampu untuk mengembangkan kemampuan untuk dapat hidup mandiri. Pada individu yang telah memasuki kehidupan perkuliahan, kemandirian seringkali berjalan beriringan dengan kebebasan (Aisyah \& Muis, 2013). Dalam hal ini kebebasan memilih pembalut pada usia mahasiswi berada pada tahap landasan minat intelektualnya. Minat, pengetahuan, dan pengalaman yang diperoleh hingga tiba pada masa remaja akhir, menghantarkan mahasiswi pada tahap pemilihan pembalut yang digunakan. Hasil penelitian ini menunjukkan bahwa pada kelompok mahasiswi yang memeroleh pengetahuan tentang reproduksi, kekhawatiran tentang kanker serviks (perceived severity) menyebabkan mahasiswi memilih pembalut yang bebas pemutih klorin. Di lain pihak, pada mahasiswi yang memiliki perceived severity kanker serviks tinggi, apabila tidak 
didukung oleh pengetahuan yang tinggi pula tentang kanker serviks, tetap memilih pembalut berdasarkan harga yang murah dan kemudahan memperolehnya.

Dalam pendekatan neurosains, otak menangkap semua rangsangan untuk dipahami (dipersepsi) melalui kerja sel saraf, sirkuit saraf, dan nemotransmitter. Sebagai contoh, ketika seseorang mengingat suatu kejadian di masa lalu, otak akan menanggapi dengan cara yang sama karena bagi otak semua itu terjadi saat ini. Otak tidak dapat membedakan antara kejadian sesungguhnya dan ingatan akan suatu kejadian (Wathon, 2016). Kebiasaan menggunakan pembalut berpemutih klorin dalam keluarga yang dicontohkan oleh ibu dari para responden, saudara perempuan para responden membuat persepsi otak memberi sinyal bahwa hal itu bukanlah hal yang perlu ditindak lanjut secara serius. Dalam persepsi mereka, orang tua mereka baik-baik saja dengan menggunakan pembalut tersebut. Meskipun kelompok yang berpengetahuan tinggi tentang kanker serviks memahami bahwa Indonesia ialah negara dengan jumlah penderita kanker serviks terbanyak di dunia, namun tetap tidak mengubah perilaku pemilihan pembalut mereka.

Ditinjau dari Psikologi Kesehatan, dari berbagai perspektif psikologis, teori belajar berhubungan erat dengan penekanan pada asosiasi dan pemodelan. Teori-teori kognisi sosial dipengaruhi oleh penekanannya pada keyakinan dan sikap. Teori tahapan pengambilan keputusan (cue to action) berhubungan dengan fokus minat mereka pada perubahan dan masa perkembangan remaja akhir. Teori pengambilan keputusan menyoroti analisis biaya-manfaat dan peran pengujian hipotesis dan teori fisiologis dengan minat mereka dalam proses biologis dan hubungannya dengan kesehatan. Hal ini sejalan dengan penelitian Aritonang (2015), bahwa sikap remaja dalam penjagaan reproduksi merupakan faktor predisposisi yang mencakup komponen seperti keyakinan, ide, konsep serta ungkapan emosional yang diekspresikan dengan tingkat laku yang berkaitan untuk bertindak. Pada remaja, hal ini dipengaruhi baik faktor eksternal maupun internal.

Weinstein (dalam Ogden, 2007) mengemukakan bahwa salah satu alasan mengapa orang terus mempraktikkan perilaku tidak sehat adalah karena persepsi yang tidak akurat tentang risiko dan kerentanan - optimisme yang tidak realistis. Dalam penelitiannya, Weinstein meminta subjek untuk memeriksa daftar masalah kesehatan dan menyatakan dibandingkan dengan orang lain tentang usia dan jenis kelamin, apa peluang subjek mendapatkan (masalah) lebih besar daripada, kurang lebih sama, atau kurang dari orang lain. Hasil penelitian menunjukkan bahwa sebagian besar subjek percaya bahwa mereka kurang mungkin untuk mendapatkan masalah kesehatan. Weinstein menyebut fenomena ini sebagai optimisme yang tidak realistis ketika dia berpendapat bahwa tidak semua orang bisa lebih kecil kemungkinannya untuk mengidap suatu penyakit. Weinstein menjelaskan empat faktor kognitif yang berkontribusi pada optimisme yang tidak realistis: 1) kurangnya pengalaman pribadi dengan masalah; 2) keyakinan bahwa masalah dapat dicegah dengan tindakan individu; 3) keyakinan bahwa jika masalah belum muncul, itu tidak akan muncul di masa depan; dan 4) keyakinan bahwa masalah tersebut jarang terjadi. Faktor-faktor ini menunjukkan bahwa persepsi risiko sendiri bukanlah proses yang rasional (Ogden, 2007).

Perilaku kesehatan individu berfungsi untuk mencapai tujuan secara efisien atau ekonomis. Dalam hal teori permainan, aksi memaksimalkan perolehan dan meminimalkan kerugian. Suatu tindakan dapat gagal untuk mencapai suatu tujuan tetapi tidak dapat menjadi sia-sia dalam arti bahwa itu akan terjadi jika tidak dirancang untuk mencapai suatu tujuan. Dengan kata lain, istilah rasional mengacu pada cara tujuan dikejar. Pada kelompok dengan 
tingkat pengetahuan tentang kanker serviks yang tinggi, pengetahuan diperoleh dari proses pembelajaran pada kurikulum Sekolah Tinggi Kesehatan.

Persepsi penguasaan pengetahuan tentang kanker serviks ditingkatkan dengan usaha atau pembelajaran dan dinilai dalam kaitannya dengan penguasaan, pengertian, atau tes pengetahuan yang dirasakan subjek penelitian. Semakin banyak individu merasa mereka telah belajar, semakin kompeten perasaan mereka. Kemampuan tinggi berarti di atas rata-rata dan kemampuan rendah berarti di bawah ratarata. Ini menyiratkan konsepsi kemampuan sebagai kapasitas yang tidak selalu terungkap dalam kinerja. Hanya upaya optimal yang mengungkap batas kemampuan seseorang dalam menghafal atau mengerjakan penugasan dari materi perkuliahan. Dengan kata lain kelompok berpengetahuan tinggi kanker serviks dalam persepsinya memiliki kompetensi knowlegde tinggi yang dinilai dari ujian dan penugasan, tanpa memerhatikan praktik/ aplikasi dari ilmu pengetahuan yang telah mereka peroleh.

Berbeda halnya dengan perceived severity, pada kelompok yang memiliki tingkat pengetahuan yang tinggi disertai perceived severity yang tinggi, mereka memilih pembalut dengan skor tertinggi yaitu memilih pembalut bebas pemutih klorin. Hal ini menunjukkan bahwa pengetahuan dan perceived severity bersama-sama meningkatkan skor pemilihan pembalut pada mahasiswi dalam hal ini usia remaja akhir. Mahasiswi yang memiliki perceived severity tinggi namun memiliki pengetahuan tentang kanker serviks yang rendah menunjukkan skor pemilihan pembalut yang rendah pula. Meskipun mereka khawatir akan keseriusan penyakit kanker serviks, namun karena tidak didasari oleh pengetahuan cara-cara mencegah kanker serviks, maka hal itu mendorong perilaku pemilihan pembalut yang salah.

\section{Simpulan}

Hasil temuan menunjukkan bahwa terjadi interaksi secara bersama antara tingkat pengetahuan dengan perceived severity terhadap pemilihan pembalut pada mahasiswi. Pengetahuan tentang kanker serviks tidak berpengaruh secara langsung terhadap perilaku pemilihan pembalut pada mahasiswi. Perceived severity berpengaruh terhadap pemilihan pembalut pada mahasiswi pada kelompok yang memiliki pengetahuan kanker serviks yang tinggi.

Dengan demikian disarankan agar pemberian pengetahuan tentang kanker serviks tidak diukur oleh tes dan penugasan saja namun bagaimana mereka mengaplikasikan dalam kehidupan seharihari. Penanaman perceived severity diperlukan untuk menerapkan pengetahuan yang diperoleh.

\section{Daftar Pustaka}

Abrori, Hernawan, A. D., \& Ermulyadi. (2017). Faktor yang berhubungan dengan kejadian keputihan patologis siswi SMAN 1 Simpang Hilir Kabupaten Kayong Utara. Unnes Journal of Public Health, 6(1), 24-34.

Aisyah, R. A., \& Muis, T. (2013). Perilaku seksual remaja pada mahasiswa Fakultas Ilmu Pendidikan Universitas Negeri Surabaya. Jurnal BK UNESA, 03(01), 364-372.

Association, E. (2009). Endometriosis and dioxins (Vol. 2200, pp. 1-103). Vol. 2200, pp. 1-103. New York: Endometriosis Association.

Badaryati, E. (2012). Faktor-faktor yang mempengaruhi perilaku pencegahan dan penanganan keputihan patologis pada siswi SLTA atau sederajat di Kota Banjarbaru tahun 2012. (Skripsi tidak diterbitkan). Universitas Indonesia, Fakultas Kesehatan Masyarakat.

Devianti, V. A., \& Yulianti, C. H. (2018). Identifikasi dan penetapan kadar klorin dalam pembalut wanita yang 
beredar di Kelurahan Ketintang dengan metode titrasi iodimetri. Journal of Pharmacy and Science, $3(1), 5-8$.

Efrida, M. (2013). Hubungan pengetahuan dan minat remaja putri dengan pencegahan kanker serviks di Madrasah Aliyah Negeri Darussalam Kabupaten Aceh Besar. (Skripsi tidak diterbitkan). Sekolah Tinggi Ilmu Kesehatan U'budiyah.

Glanz, K., Rimer, B. K., \& Viswanath, K. (2008). Ecological models of health behavior. Dalam Health behavior and health education: Theory, research, and practice. John Wiley and Sons. doi.org/10.7326/0003-4819-116-4350_1

Grau, M. J. (2013). Cognitive phenomenology: A non-reductive account. (Dissertation). Universitat de Barcelona.

Julina. (2012). Analisis perilaku konsumen perempuan terhadap kesehatan reproduksi dan perilaku penggunaan pembalut. Marwah: Jurnal Perempuan, Agama dan Gender, 11(1).

Kaur, R., Kaur, K., \& Kaur, R. (2018). Menstrual hygiene, management, and waste disposal: Practices and challenges faced by girls/women of developing countries. Journal of Environmental and Public Health, 2018(5), 1-9. doi.org/10.1155/2018/1730964

Kementerian Kesehatan RI. (2015). Infodatin Reproduksi Remaja-Ed.Pdf (pp. 1-8). pp. 1-8. https://doi.org/24427659

Kementerian Kesehatan RI Pusat Data dan Informasi Kesehatan. (2015). Stop kanker. Pusat Data Dan Informasi Kementerian Kesehatan RI, 1-8. https://doi.org/10.1017/CBO97811074 15324.004

Kusumawati, Y., Wiyasa, R., \& Rahmawati, E. N. (2016). Pengetahuan, deteksi dini dan vaksinasi HPV sebagai faktor pencegah kanker serviks di Kabupaten Sukoharjo. Jurnal Kesehatan Masyarakat, 11(2), 204-213.

Lordo, R. F. (2018). The importance of interdisciplinarity: Redefining the health belief model (Senior theses). Vol. 220. Retrieved from https://scholarcommons.sc.edu/senior_ theses/220

Na'mah, L. U. (2014). Seks pranikah remaja (penyebab, perilaku, dan dampak): Studi kasus kelompok mahasiswa dan remaja SMA di Kabupaten Kebumen. (Tesis tidak diterbitkan). Universitas Sebelas Maret Surakarta.

Nurachmah, E., \& Mutikasari. (2009). Faktor pencegahan HIV/ AIDS akibat perilaku berisiko tertular pada siswa SLTP. Makara Kesehatan, 13(2), 6368.

Ogden, J. (2007). Health psychology (4th ed.). England: Mc Graw Hill.

Purwatiningsih, S. D., \& Puspitasari, I. (2006). Sosialisasi pesan "pencegahan kanker serviks" oleh Yayasan Kanker Indonesia terhadap pengetahuan mencegah penyakit kanker serviks (Survei pada ibu-ibu pengajian Majelis Ta'lim Nurul Falah Kota Tangerang). UPI YAI, Fakultas Ilmu Komunikasi.

Rasjidi, I. (2009). Epidemiologi kanker serviks. Indonesian Journal of Cancer, III(3), 103-108.

Schecter, A., Birnbaum, L., Ryan, J. J., \& Constable, J. D. (2006). Dioxins: An overview. Environmental Research, 103(3), 419-28.

DOI:10.1016/j.envres.2005.12.003

Septadina, I. S., Kesuma, H., Handayani, D., Suciati, T., \& Liana, P. (2015). Upaya pencegahan kanker serviks melalui peningkatan pengetahuan kesehatan reproduksi wanita dan pemeriksaan metode IVA (inspeksi visual asam asetat) di wilayah kerja puskesmas. Jurnal Pengabdian 
Sriwijaya, 222-228.

Setyowati, I. (2012). Menaklukkan kanker serviks dan kanker payudara dengan 3 terapi alami. Universitas Muhammadiyah Surakarta.

Society, A. C. (2016). Cervical cancer causes, risk factors, and prevention what are the risk factors for cervical cancer. American Cancer Society, 7-9. doi.org/10.1097/IJG.0b013e3181ca76 c4

Sur, B. (2015). Examining perceived susceptibility of illness and health protective behaviors among emerging adults with familial risk for type 2 diabetes. (Thesis). Ohio University, Faculty of the College of Arts and Sciences.

Tan, U. (2007). The psychomotor theory of human mind. International Journal of Neuroscience, 117(8), 1109-1148. doi.org/10.1080/00207450600934556
Tantry, Y. U., Solehati, T., \& Yani, D. I. (2019). Gambaran pengetahuan, sikap, dan perilaku perawatan diri selama menstruasi pada siswi SMP. Jurnal Ilmu Keperawatan dan Kebidanan, 10(1), 146-154. doi.org/10.26751/jikk.v10i1.531

Tempo. (2015). Daftar merek pembalut berklorin temuan YLKI. pp. 1-5.

Wahyuni, S. (2013). Faktor-faktor yang mempengaruhi perilaku deteksi dini kanker serviks di Kecamatan Ngampel Kabupaten Kendal Jawa Tengah. Jurnal Keperawatan Maternitas, 1(1), 55-60.

Wathon, A. (2016). Neurosains dalam pendidikan. Jurnal Lentera: Kajian Keagamaan, Keilmuan, dan Teknologi, 14(1), 284-294.

Wulandari, A. S. (2016). Pengertian dan pemahaman resiko CA cervix pada wanita usia subur di Indonesia. Jurnal Promkes, 2(1), 58-65. 